\title{
Cyclical Tendencies in the Later Music of Erik Satie (1866-1925)
}

In memoriam Lloyd Rodgers

\section{Nors S. Josephson}

After receiving his diploma from the Schola Cantorum in 1908, Satie embarked on a series of large-scale instrumental and vocal works. These ambitious compositions all utilize innovative intervallic and key relationships that partly derive from earlier cyclical techniques of the late $18^{\text {th }}$ and $19^{\text {th }}$ centuries.

Already his magnificent piano masterpiece Sports et Divertissements (1914) ${ }^{1}$ displays several noteworthy cyclical characteristics. Fortunately, we possess Satie's original ordering of the 21 pieces, which authorized the pianist Marcelle Meyer to give the premiere recital in $1922 .^{2}$

It is evident that Satie groups the first ten numbers around a clear circle-offifths, $\mathrm{C}-\mathrm{G}-\mathrm{D}-\mathrm{A}-\mathrm{E}-\mathrm{b}$. The remaining eleven pieces then present a descending progression around E-D-C. It is instructive to compare this 1922 ordering with that of the 1923 publication (Lucien Vogel), where Satie's pieces nos. 1-5 emphasize the third- and second-related tonal centers $\mathrm{C}(1,3-5)$ and $\mathrm{E}$-dorian (2). Moreover, in the 1923 version nos. 1 and 3-4 also exhibit the same modal colorings on $\mathrm{A} b$ and $\mathrm{B} b$ (or $\mathrm{C}$ : $b \mathrm{VI}$ and $b \mathrm{VII}$ ). A more tonal conclusion on $\mathrm{C}$-major - with a preceding plagal, cadential preparation on $\mathrm{F}-\mathrm{C}$ - is found at the end of no. 5, whose secondary ii (d)-I (C) movement also recalls no. 2. A comparable, complementary response on the pitches, $\mathrm{C}-\mathrm{E}$ is then encountered at the close of no. 14 (Les Quatre-Coins) and 17 (end of Tango). This diatonic framework on $\mathrm{C}-\mathrm{E}$ is further buttressed by the E-pieces nos. 11 (Golf), 13 (Les Courses, with analogous third motives around b, $\mathrm{c} \#$ and a), 18 (Le Traîneau) and 21 (Le Tennis). Furthermore, the vivacious no. 19 (Le Flirt) is set in the related G (/C) orbit.

The 1923 edition also groups the individual numbers according to instrumental genres. Thus nos. 15-17 constitute three scherzo-like dances in the style

1 On the publications of Sports et Divertissements, see Stefan Ulrich, "Erik Saties Sports et Divertissements: Ton, Bild, Wort", Archiv für Musikwissenschaft 59 (2002): 116-118.

2 See Caroline Potter, Erik Satie: Music, Art and Literature (Farnham, Ashgate Publishing Ltd., 2013), 291 for her listing of Satie's 1922 piece order for Sports et Divertissements, which authorized Marcelle Meyer to give the premiere recital. 
Table 1: Original Sequence of Pieces in Sports et Divertissements

\begin{tabular}{lll}
\hline Original Title & English Title & Tonal Centers \\
\hline Chorale inappétissant & Unappetizing Chorale & $(\mathrm{B} b-) \mathrm{C}$ \\
Le Bain de Mer & Sea Bathing & $\mathrm{G}$ \\
Le Water-chute & Shooting the Chute & $\mathrm{D}$ \\
La Pieuvre & The Octopus & $\mathrm{G} \sharp-\mathrm{D} b$ \\
Colin-Maillard & Blind Man's Buff & $(\mathrm{E}-) \mathrm{A}$ \\
Le Golf & Golf & $\mathrm{E}$ \\
Le Flirt & Flirtation & $\mathrm{G}$ \\
Le Carnaval & Carnival & $\mathrm{B} b$ \\
Le Tennis & Tennis & $\mathrm{e}$ \\
Tango & Tango & $\mathrm{b}-\mathrm{C}$ \\
Le Réveil de la Mariée & Awakening the Bride & $\mathrm{d}-\mathrm{C}$ \\
Le Yachting & Yachting & $\mathrm{F} \sharp-\mathrm{B}$ \\
Le Traineau & Sleighing & $\mathrm{A}-\mathrm{e}$ \\
La Chasse & Hunting & $\mathrm{D}-\mathrm{C}$ \\
Les Courses & The Races & $\mathrm{E} / \mathrm{A}$ \\
Les Quatre-Coins & Puss in the Corner & $\mathrm{C} / \mathrm{B}-\mathrm{C}$ \\
Le Pique-nique & Picnic & $\mathrm{B} b$ \\
La Pêche & Fishing & $\mathrm{D}$ \\
Le Feud'Artifice & Fireworks & $\mathrm{d}$ \\
La Balançoire & Ina Swing & $\mathrm{e}$ \\
La Comédie italienne & Commedia dell'Arte & $\mathrm{C}$ \\
\hline & &
\end{tabular}

of ragtime, waltz and tango. Similarly, the rather impressionistic nos. 7-9 function as a slow movement, or lyrical interlude. Together with the A-major cascades of no. 6 (Colin-Maillard) they outline an upper fourth/third aggregate on $\mathrm{A}-\mathrm{D}-\mathrm{f} \#-\mathrm{G}$ that extends the earlier matrix on $\mathrm{C}-\mathrm{e}-\mathrm{g}$ found in nos. $1-5$. Here one is distinctly reminded of Stravinsky's love of superimposed fifth sonorities (compare the outset of Petrouchka, 1911 with its polytonalities on D and G). Satie's accentuation of A-major in nos. 6, 13 (:plagal auxiliary of E), 16 (:initial modulation from the opening D-major), 18 (another plagal tributary of the final E) and finally 20 (ultimate link to no. 21's e) also prepares for the eventual return to the opening matrix of no. 2 .

Sports et Divertissements thus evinces a carefully drafted, freely cyclical structure that distantly echoes certain symphonic prototypes from the $19^{\text {th }}$ century, 
notably Schumann's Carnerval op. 9 and Second Symphony op. 61, in addition to Musorgsky's Pictures at an Exhibition (1874) - an artist much admired by both Satie and his composer-friend Debussy. As we shall observe, Satie's Sports et Divertissements directly impacted many salient features of his future cubistic ballet Parade (1917) - which also begins with a stately Choral, an opening $\mathrm{C}$-mixolydian-E-matrix and superimposed triads on $\mathrm{C}-\mathrm{E}-\mathrm{G}$ and $\mathrm{G}-\mathrm{D}-\mathrm{B}-\mathrm{D} \sharp-$ $\mathrm{F} \sharp-\mathrm{A}$. To be sure, Parade devotes even more attention to linear continuity, in particular stressing the tonic C's plagal orbit on $\mathrm{F}$ in measures 2-4, 109-112 (trombones), 401-464, 537-545 and 634-643. In the last three instances the bass line's F's resolve down to the even more stable $\underline{\mathrm{E}}$ and the latter's associated $\mathrm{C}$-major sphere. Frequently Satie links these $\underline{\mathrm{E}}$-reprises to underlying quartal figurations (such as $e^{1}-a^{1}-d^{2}$ in measures 465-470ff. and E-A in 605-607) that reinvoke the initial fourth bases of the Choral, 1-8 (such as the trumpet's lines on $c^{1}-f^{f}$ and $g^{1}-c^{2}$ ) and 20-22 (violoncelli's quartal fugato motives on $\mathrm{g}-\mathrm{d}$ and e-B). Related fourth ideas recur in measures 45 (clarinet) and 95-104 (brass).

Satie's incorporation of Parade's opening seminal gestures eventually leads to wholesale recalls of other earlier themes, as follows:

Table 2: Recurring cyclical themes in Parade (including 1919 additions) ${ }^{3}$

\begin{tabular}{lll}
\hline Initial appearance & Measures & Later recurrences \\
\hline Choral fugato & $24-34(\mathrm{C}: \mathrm{V}$-modulating) & $677-684$ (clearer C-major) \\
Coloristic A-major scales & $35-38$ & $578-579+624-629$ \\
Chinese conjuror & $45-86(\mathrm{e}-\mathrm{C})$ & $550-570+656-668$ (clear C) \\
Transition + March & $87-104(\mathrm{D}-\mathrm{G})$ & $200-217($ again D-G) \\
Music hall style & $296-319(\mathrm{C})$ & $588-603(\mathrm{G})$ \\
Acrobats & $\begin{array}{l}389-465(\mathrm{C}-\mathrm{E} \text { with ex- } \\
\text { tensive whole-tone II) }\end{array}$ & $525-549(\mathrm{C})$ \\
& & \\
\hline
\end{tabular}

Satie supports this grandiose symphonic apotheosis with recurring harmonic underpinnings, notably an omnipresent whole-tone scale II (on $\mathrm{C} \sharp / \mathrm{D} b-\mathrm{E} b-\mathrm{F}$ ) that is already strongly in evidence during the initial Choral as the $d \sharp^{1}$ in m.1 and the $d b^{1}$ in m. 6 testify. The whole-tone II flavor of the Choral is freely recapitulated during the central transition in mm. 184-199 (see Mus. Ex. 1).

3 Compare Robert Orledge, Satie the Composer (Cambridge, Cambridge University Press, 1990), 172 (in 1919 Satie added the final measures 1-19 and 572-676). See also p. 173 for a comprehensive chart of Parade with its principal cyclical themes. 


\section{Musical Example 1: Parade}

a) Choral, 1+6-7 (:reduction)

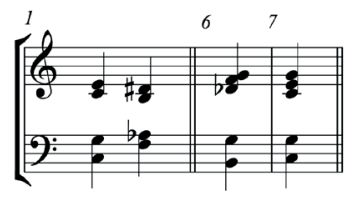

b) Transition, 184-199 (reduction)

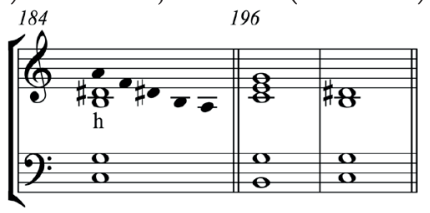

Since this recall is coupled with a reiteration of the previous transition (87-94) in mm. 200-207, Satie thus produces a circular spiral effect that is in keeping with the cubistic ${ }^{4}$ aesthetic of Parade. A similar passage occurs in mm. 252-267, whose ethereal, static colors are summarized in Mus. Ex. 2.

Musical Example 2: Static ethereal harmonies in Parade, 252-267

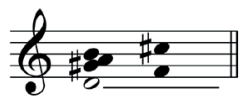

Since the surrounding episodes stress b-minor (226-229), F-major (244245+268-269) and Db-major (272-275), Satie smoothly reenforces the prevailing whole-tone II orbit that is increasingly geared to F.

The third movement - Acrobats - is also punctuated by whole-tone II episodes in F, notably in 401-404, 429-448 and 537-540. To be sure, these are balanced by more stable statements of the recurring $\mathrm{C}-\mathrm{E}-\mathrm{G}-\mathrm{B}$ orbit, notably in the central mm. 344-348 and again in 585-595 (B-G-E-C). Satie finally resolves the modal echoes of whole-tone II (as the two central pitches of Eb and D $b$ ) during the quote of Musorgsky's Boris Godunov in 669-676 (see Mus. Ex. 3) and the coda-like recall of the Choral in 682-684 (Mus. Ex. 4).

4 On the artistic links between cubism and Satie's Parade, see Franziska Kollinger, "Saties »Parade« (1917) als Entwurf einer neuen französischen Musik", Archiv für Musikwissenschaft 71 (2014): 37-40. 
Musical Example 3: Parade's quote from Musorgsky's Boris Godunov IV: i

a) Parade, 673-676

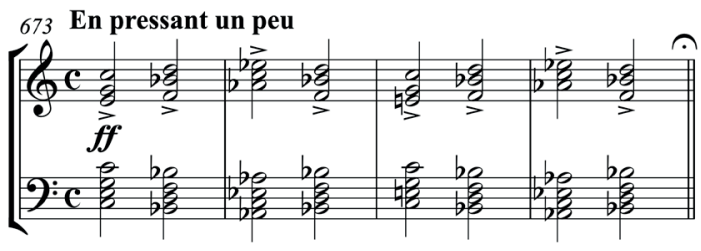

b) Boris Godunov IV: i, 110-113 (:reduction)

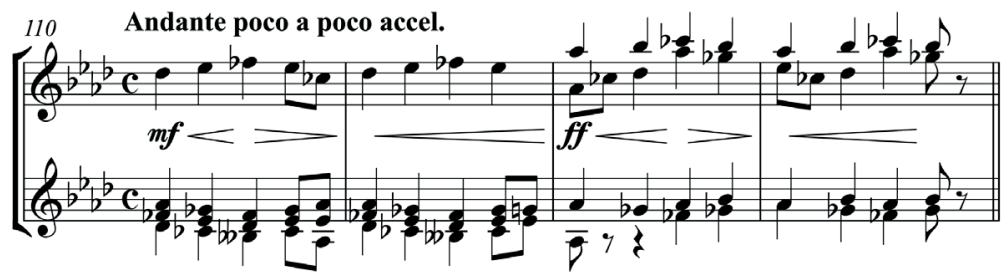

And the denunciation of the Pretender shall be announced in all villages and cities, in all of Russia, read in all churches, squares and meetings ...

Musical Example 4: Parade's closing bass line in 682-684

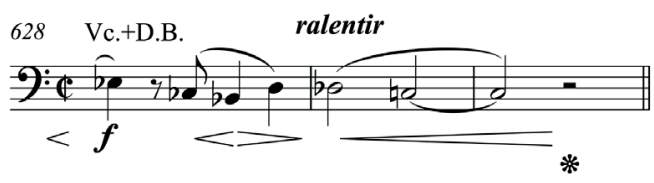

Satie's symphonic drama Socrate (with vocal parts) dates from 1918, while his orchestration was first performed in 1920. Here our French composer takes the tightly-knit organic flow of Parade one step further and derives the score's entire harmonic and linear content from the opening sixteen measures ${ }^{5}$ (see Mus. Ex. 5).

Musical Example 5: Basic Cell of Socrate: i (Portrait de Socrate), mm. 1-16

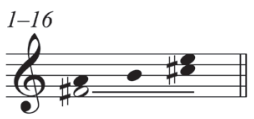

5 See Robert Orledge, "Satie” in The New Grove Dictionary of Music and Musicians 22 (2001), 318. Here the author comments on Satie's "linear logic in the succession of motifs and a more horizontal, continuous approach ..." 
In particular, the first movement's emphatic downbeat in mm. 29-33 - with its superimposed fifths on $e^{1}+b^{1}$ and $f \sharp^{1}+c \sharp^{2}-$ is clearly founded on the Basic Cell of Mus. Ex. 5. Analogous derivations with elegant linear oscillations are encountered in mm. 46-49, 57-58, 67-69, 88-96, 119-123 and especially the pronounced reprise in 134-142 (see Mus. Ex. 6).

Musical Example 6: Basic Cell Variations in Socrate: i

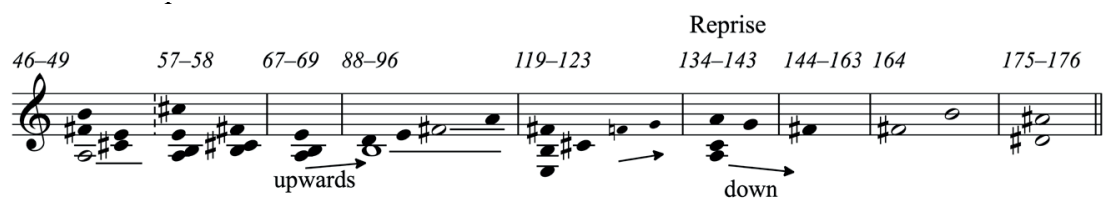

Similar linear movements around the Basic Cell permeate the flowing, dancelike second movement, including the $\underline{\mathrm{B}}$-oriented measures $213+274-275$ (see Mus. Ex. 7).

Musical Example 7: Basic Cell Variations in Socrate: ii

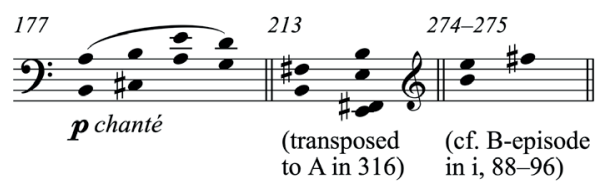

The opening in m. 177f. is then transposed up a fifth to $e^{2}-f \sharp^{2}-b^{2}-a^{2}$ in $232-235$. The same $\underline{E}$-center is subsequently employed as a temporary tonic for the wave figure in 308-309, which will eventually become the principal theme of the finale (see Mus. Ex. 8).

Musical Example 8: Wave figure in ii becomes Finale opening, 383

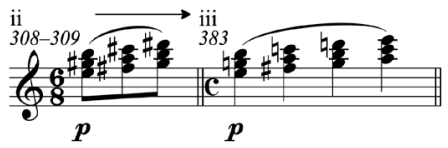

The reprise sensation in 232f. is further strengthened by the reappearance of the episodic, rocking figurations of 213f. in 316f, (here moved downwardly from B to $A[E-B]$ in the style of Socrate: i, 88f.). Finally, the return of the initial Basic Cell variation (ii, 177) in 349-382 is now cushioned by a gentle D-plagal close in 381-382 (see Mus. Ex. 9). 
Musical Example 9: D-plagal close in ii, 381-382

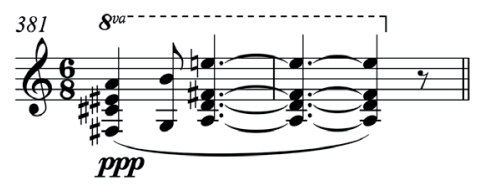

The final section of Socrate (entitled, Mort de Socrate) is - as mentioned above - based on the E-major wave figure from ii, 308-309. Again Satie chooses a transparent binary form with a clear reprise in iii, 537-543 (cf. the initial $\mathrm{mm}$. 383-390). The ensuing episode in C-Lydian, mm. 391-394 is transposed (in the recapitulation) down to A- and F-Lydian, mm.544-551. Increasingly the main opening theme from 383f. dominates the moving close of the tragedy. First Satie stresses the refrain's beginning two pitches on $\underline{\mathrm{A}-\mathrm{B}}+\underline{\mathrm{D}-\mathrm{E}}$ in mm. 445-446 and then prolongs the $\mathrm{D} / \mathrm{d}-\mathrm{Phrygian}$ sphere in $467-483$. Like the second movement's ending on D-major, the finale's D-areas may be heard as a weak subdominant of the final A-tonic in 658-674. Moreover, Satie's reprise also integrates the D harmony into broader circular progressions around E (537-539 and 640-653)-A (658-674)-D (552-554). In addition, Satie inserts two preparatory refrains in B (:a kind of secondary dominant of the tonic A) in 566-569 and 654-655 to highlight the final climactic resolution of $\mathrm{E}$ to A. Significantly, B also acts as an appoggiatura or upper neighbor note to the lower A in the style of Socrate: $i$ and ii at the poignant moment of Socrates' physical death in mm. 670-672 (with the emphatic vocal monotone on $b^{1}$ !). The final cadence on $\mathrm{A} / \mathrm{E} \sharp-\mathrm{F} \#$ again recalls ii's ending and i's emphasis on $\mathrm{F} \sharp$.

$* * *$

Satie's ensuing ballet Mercure was first performed in June, 1924 and utilizes many compositional advances of Socrate. Here, too, our French composer presents an extremely integrated tonal framework around Mercure's central F-major, ${ }^{6}$ particularly in nos. 1, 3, 5 and the closing nos. 10+12-13: two vivacious Polkas and a lighthearted Marche-Finale, which reinvoke the upbeat mood of the introductory Marche-Ouverture, no. 1. These sections frequently present Mercure's flippant motto theme or free metamorphoses thereof (compare Socrate's Basic Cell and its ensuing free variations; see Mus. Ex. 10).

6 See Robert Orledge, “Satie's Ballet 'Mercure' (1924): From Mount Etna to Montmartre”, Journal of the Royal Musical Association 123 (1998): 232-245.Originally nos. 4 and 6 were only set in C (minus the D-beginnings), and no. 8 (Fuite de Mercure) was introduced in Bb, F's milder subdominant. Satie also toyed with a subsidiary tonal realm on $\mathrm{C} \sharp / \mathrm{Db}$ in nos. 7-8. 
Musical Example 10: Mercure's Motto Theme and its Metamorphoses

a) Mercure's Motto Theme in no. 1, 18-19 and no. 5, 1-2

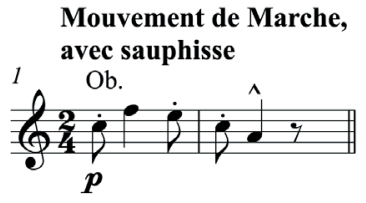

b) Mercure's Escape in no. 8,1-2

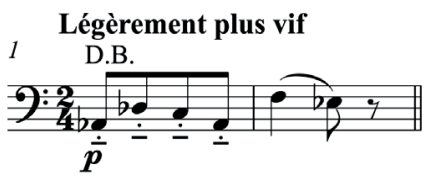

c) Rape of Proserpine in no. 13, 1-3

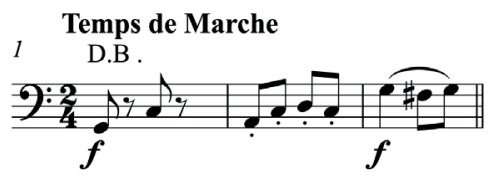

In addition, no. 9's C-major (Colère de Cerbère) and no. 12's C-Polka (Chaos) plus no. 11's A-major (Nouvelle Danse) outline C and A, or the upper fifth and third of F-major's tonic triad (a similar triadic group was originally present in nos. $3-5$, since no. 5 was originally set in A). Moreover, F-major's dominant, C, is also conspicuously present at the outset of no. 3 (Danse de Tendresse), mm. 5-8 and also at the close of no. 4 (Signes du Zodiaque), mm. 26-30. Finally, F's relative minor of $\mathrm{d}$-minor is the key of the nocturnal love-scene in no. 2 between Apollo and Venus, and originally also appeared at the outset of the final no. 13. D-minor's transformation into its corresponding D-major at the beginning of nos. 4 (Signes $d u$ Zodiaque) and 6 is soon resolved via traditional circle-of-fifths to $\mathrm{C}$ (no. 4 ) and two deceptive A/Bb cadences in no. 6, mm. 8-9 and 46-47. No. 6's tonal fluctuations between $\mathrm{A}$ and $\mathrm{B} b$ are eventually resolved to no. 11's A-major, and no. 6's final $\mathrm{B} b$-major sets in motion a complementary circle-of-fifths in nos. 7-8 around the flat keys $\mathrm{B} b-\mathrm{E} b-\mathrm{A} b-\mathrm{C} \sharp-\mathrm{F} \sharp-\mathrm{B}-\mathrm{E}-\mathrm{A}-\mathrm{D}-\mathrm{G}-\mathrm{C}-\mathrm{F}-\mathrm{d}-\mathrm{C}$ (:a mirror image of the circle-of-fifths in no. 4). It is this very compelling synthesis between neo-Classical rondo form (:Mercure's motto metamorphoses), systematic tonal/intervallic logic and fluctuating dance numbers that lends Mercure its irresistible charm.

As in Parade and Socrate, Satie's Mercure also provides for surface continuity between the individual numbers. Thus the two nostalgic waltzes in nos. 3 and 
6 - which terminate on $\mathrm{F}$ and its subdominant $\mathrm{B} b$ - are also linked motivically through their consistent upbeat fourth patterns, as in no. 3, mm. 17-20 and no. 6 , mm.10-15f.+21-26f. Likewise, the Three Graces' nos. 6 and 7 share the same identical motivic outlines of the falling seventh and ensuing rising third (see Mus. Ex. 11).

Musical Example 11: Recurring Graces' Melody

a) Danse des Graces in № 6,1

\section{Mouvement de Valse}

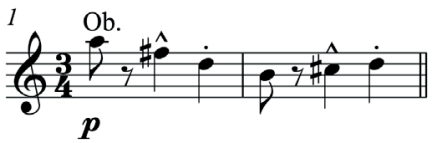

b) Bain des Graces im № 7,1

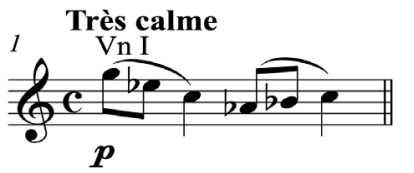

Significantly, this melodic link also underscores the circular fifth spiral between the keys of $\mathrm{B} b, \mathrm{E} b$ and $\mathrm{A} b$ that initiates the important circle-of-fifths that will eventually lead back to the F-tonic. These flat keys are also present in a linear sense during the final cadence of no. 13's Finale (see Mus. Ex. 12):

Musical Example 12: Finale: Rapt de Proserpine

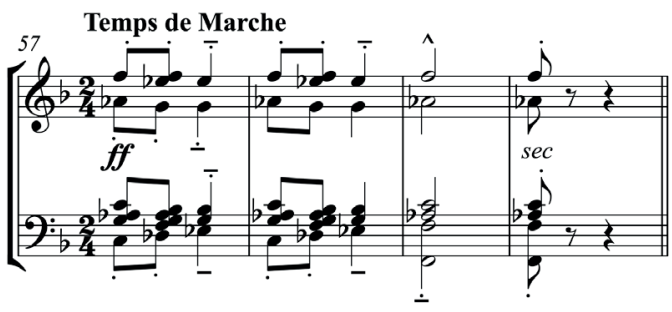

Satie's last dadaist ballet Relâche also dates from 1924 and shares many stylistic features with Mercure. These include an extremely cohesive tonal structure - here based on the third cells (tonic) D, F and A - and interlocking popular song refrains (such as Le Marchand de Navets and Savez-vous planter des choux) with lyrical waltz episodes. Moreover, Mercure's clear formal tendency towards march-like structural recapitulations (as Mercure's witty refrain and the two circle-of-fifths episodes) is here expanded into a gigantic palindrome for the entire composition: 
Table 3: Relâche's Structural Palindrome ${ }^{7}$

\begin{tabular}{|c|c|c|c|c|c|}
\hline Part I & $\mathrm{Mm}$. & Keys & Part II & $\mathrm{Mm}$. & Keys \\
\hline $\begin{array}{l}\text { Refrain (with } \\
\text { two episodes) }\end{array}$ & $\begin{array}{l}1-53 \\
143-180\end{array}$ & $\begin{array}{l}\text { D-A-G- } \\
-\mathrm{D}-\mathrm{B} b\end{array}$ & $\uparrow$ & $777-814$ & $\mathrm{C}-\mathrm{B} b-\mathrm{F}$ \\
\hline $\begin{array}{l}\text { Pivot } \\
\text { harmonies }\end{array}$ & $53-59$ & $\mathrm{C}-\mathrm{g}-\mathrm{C}$ & $\begin{array}{l}\text { Dancer puts } \\
\text { crown on lady } \\
\text { spectator's head }\end{array}$ & $771-777$ & $\mathrm{C}-\mathrm{g}-\mathrm{C}$ \\
\hline $\begin{array}{l}\text { Episode } 1 \\
\text { (developed } \\
\text { from 17-25) }\end{array}$ & $\begin{array}{l}60-81+267- \\
296 \text { (Men) }\end{array}$ & $\begin{array}{l}\mathrm{F} \\
\mathrm{C}\end{array}$ & Close of ballet & $835-866$ & $\mathrm{D}$ \\
\hline $\begin{array}{l}\text { Episode } 2 \\
\text { developed } \\
\text { from seconds } \\
\text { in } 33-35\end{array}$ & $\begin{array}{l}\text { 90-109 } \\
\text { (Woman's } \\
\text { entry) }\end{array}$ & $\begin{array}{l}A(e-f \sharp- \\
-c \sharp-b \sharp)\end{array}$ & $\begin{array}{l}\text { Woman's } \\
\text { re-entry; she } \\
\text { sits down on } \\
\text { a sofa (+Further } \\
\text { development in } \\
\text { II, 688f. with } \\
\text { inversions of } \\
\text { second and fifth) }\end{array}$ & $\begin{array}{l}515-554 \\
+815-834\end{array}$ & $\begin{array}{l}\mathrm{F}-\mathrm{B} b-\mathrm{D} b- \\
\mathrm{B} b\end{array}$ \\
\hline $\begin{array}{l}\text { Episode } 2 \\
\text { varied from }\end{array}$ & $\begin{array}{l}\text { 184-194 } \\
\text { (Danse de }\end{array}$ & $\mathrm{G}-\mathrm{A}$ & $\begin{array}{l}\text { Danse de la } \\
\text { couronne }\end{array}$ & $720-725$ & A \\
\hline $\begin{array}{l}33-41 \\
\text { Men }\end{array}$ & $\begin{array}{l}\text { la porte } \\
\text { tournante) } \\
233-266\end{array}$ & $\mathrm{E}$ & $\underline{\text { Men's re-entry }}$ & $\begin{array}{l}466-514 \\
\text { (expanded!) }\end{array}$ & A-F-A \\
\hline $\begin{array}{l}\text { Finale (partly } \\
\text { based on } \\
\text { the popular } \\
\text { song Cadet } \\
\text { Rousselle) }\end{array}$ & $361-428$ & G & & $\begin{array}{l}429-440 \\
+455-460 \\
+571-587\end{array}$ & $\begin{array}{l}A \\
G \\
G-D\end{array}$ \\
\hline
\end{tabular}

Satie's return to the two episodes from Part I, mm. 233f.+361f. at the outset of Part II (429f.+466f.) is also underscored by the latter's clearer tonal stress on (tonic) D's IV (G) and V (A) degrees. Of special note is the resurgence of the

7 This chart was compiled independently by the present author (with more detailed measure equivalences and key listings). Later he became acquainted with the similar diagrams in Orledge's Satie the Composer, 180 and Grete Wehmeyer's Erik Satie (Regensburg, Bosse, 1974), 272. I am especially indebted to Wehmeyer's comprehensive listing of the principal French popular song titles. The reader is also referred to Courtney S. Adams' valuable essay, Erik Satie and Golden Section Analysis, in Music and Letters 77 (1996), 242-252, where the author mentions that Golden Sections frequently involve a division of a composition into two parts. Furthermore, her examination of all three-movement piano sets by Satie that were written between August 1914 and October 1919 reveals that these display exact Golden Section proportions among their respective movements. 
flatted submediant $\mathrm{B} b$ - an incidental, subordinate pitch in Part I (cf. 143-180), but far more crucial at the close of Relâche. Here $\mathrm{B} b$ increasingly acts as a modal dominant substitute for $\mathrm{A}$, the latter being more significant at the outset of Part II and during the symphonic entr'acte Cinema. ${ }^{8}$ The latter movie music features a rondo form in A with an episode in D, linking it even more smoothly to Relâche's pitch structures. Moreover, Marks points out ${ }^{8}$ that this entr'acte features oscillating patterns in its first section that are repeated in a different order during a later point, similar to Satie's linking his two acts in Relâche itself. Likewise, Cinema's scherzo-like and lyrical, reposeful episodes also recall the similar mood contrasts in Relâche.

In summary, Relâche's palindrome tendencies may be viewed as a further extension of Parade's comprehensive cyclical architecture, with whom it shares a love for tertial spirals (such as D-F-A). Relâche's impressive intervallic metamorphoses - especially those of the feminine complex from m. 33f. - also recall similar tendencies in Sports et Divertissements and notably Socrate. Moreover, especially Part I utilizes consistent upward chromatic introductions that - in conjunction with the backwards-oriented palindrome - create an ongoing flow and the sense of a perpetual, non-directional transition (see Mus. Ex. 13).

Musical Example 13: Recurring Chromatic Transitions in Relâche

a) №1 Ouverturette, 2-9

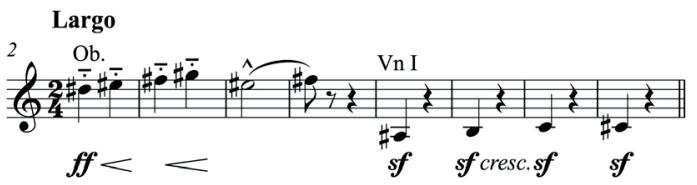

b) №2 Rideau, 82-85

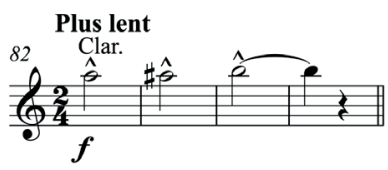

c) №5 Entrée de Borlin, 143-145

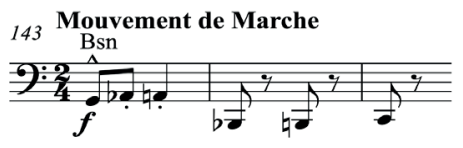

8 See Martin Marks, “The Well-Furnished Film: Satie's Score for 'Entr'acte”, Canadian University Music Review 4 (1983): 254-255. 
d) №6 Danse de la porte tournante, 181-185

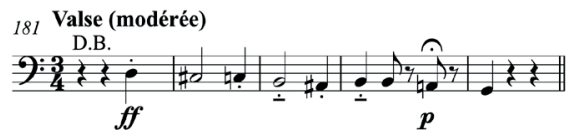

e) №8 Danse des hommes, 267-270

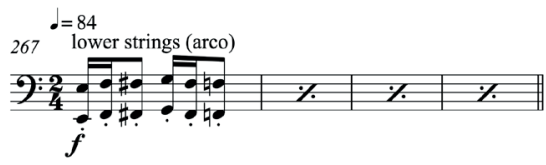

f) №9 Danse de la femme, 297-300

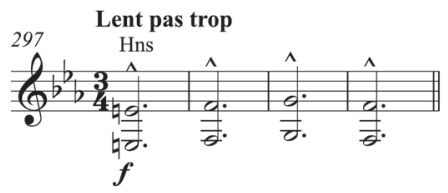

g) №15 Danse de Borlin et de la femme, 588-591

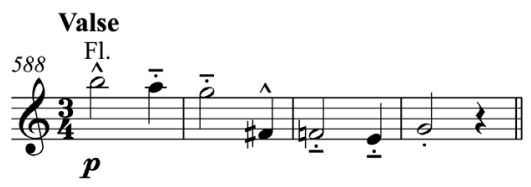

As the librettist Francis Picabia described Relâche, Satie's ballet was a description of "life with no tomorrow, life of today, car headlights, pearl necklaces, the curved slender forms of women, publicity, music, cars, men in evening dress, movement, noise and play ..." Thus we may see Relâche as a fitting climax to Satie's innovative achievements of the 1910's and 1920's.

\section{Cyclical Tendencies in the Later Music of Erik Satie (1866-1925)}

\section{Abstract}

After receiving his diploma from the Schola Cantorum in 1908, Satie embarked on a series of large-scale instrumental and vocal works. These ambitious compositions all utilize innovative intervallic and key relationships that partly derive from earlier cyclical techniques of the late $18^{\text {th }}$ and $19^{\text {th }}$ centuries. This article presents an analysis of the cyclical tendencies in the later music of Erik Satie.

9 See Keith Andersen, linear notes for the NAXOS CD 80554279 recording by Jérôme Kaltenbach conducting the Orchestra Symphonique et Lyrique de Nancy. 


\section{Cyklické tendence v pozdní hudbě Erika Satie (1866-1925)}

\section{Abstrakt}

Po obdržení diplomu na Schola Cantorum v roce 1908 se Satie pustil do řady rozsáhlých instrumentálních a vokálních děl. Všechny tyto ambiciózní skladby využívají inovativní intervalové a tonální vztahy, které částečně vycházejí z dřívějších cyklických technik z konce 18. a 19. století. Tento článek představuje analýzu cyklických tendencí v pozdější hudbě Erika Satie.

\section{Keywords}

music analysis; Erik Satie; cyclical techniques

\section{Klíčová slova}

hudební analýza; Erik Satie; cyklické techniky

Nors S. Josephson

Independent scholar

ingo.weber-musik@vodafonemail.de 